\title{
Scab of Wheat and Barley: A Re-emerging Disease of Devastating Impact
}

Marcia McMullen

North Dakota State University, Fargo

\section{Roger Jones}

University of Minnesota, St. Paul

\section{Dale Gallenberg}

South Dakota State University, Brookings
$\mathrm{S}_{\mathrm{ith}}$ ab can be a devastating disease affecting all classes of wheat and other small grains. This fungal disease, also called Fusarium head blight (FHB), has the ability to completely destroy a potentially high-yielding crop within a few weeks of harvest. Lush, green fields become blighted seemingly overnight (Figs. 1 and 2). Frequent rainfalls, high humidities, and/or heavy dews that coincide with the flowering and early kernel-fill period of the crop favor infection and development of the disease. Damage from head scab is multifold: reduced yields, discolored, shriveled "tombstone" kernels (Figs. 3 to 5), contamination with mycotoxins, and reduction in seed quality. The disease also reduces test weight and lowers market grade. Difficulties in marketing, exporting, processing, and feeding scabby grain are experienced.

In North America, Fusarium graminearum Schwabe (teleomorph Gibberella zeae (Schwein.) Petch; synonym $=G$. saubinetti) predominates among several Fusarium species that can cause scab $(4,5,8,40,48,60)$. Other species may predominate in cooler climates or where crops other than wheat and corn are dominant $(8,40,48,60)$. F . graminearum also is associated with stalk and ear rot of corn and may cause a root rot of cereals. The fungus persists and multiplies on infected crop residues of small grains and corn. The chaff, light-weight kernels, and other infected head debris of wheat and barley, returned to the soil surface during harvest, serve as important sites of overwintering of

Dr. McMullen's address is: Plant Pathology Department, 303 Walster Hall, North Dakota State University, Fargo 58105

E-mail: mmcmulle@ndsuext.nodak.edu

Publication no. D-1997-0902-04F

(c) 1997 The American Phytopathological Society the fungus. Continued moist weather during the crop growing season favors development of the fungus, and spores are windblown or water-splashed onto heads of cereal crops. Wheat and barley are susceptible to head infection from the flowering (pollination) period up through the soft dough stage of kernel development. Spores of the causal fungus may land on the exposed anthers of the flower and then grow into the kernels, glumes, or other head parts. Excellent descriptions of the disease cycle and spore stages of the causal fungi have been published $(4,8,21,40,48)$.

Mycotoxins are frequently associated with the growth and invasion of cereal grains by scab fungi. The most common toxin associated with $F$. graminearuminfected grain is vomitoxin (deoxynivalenol). Vomitoxin is known to cause vomiting and feed refusal in nonruminant animals and poses a threat to other animals and humans if exposure levels are high (45). The presence of mycotoxins in infected grain further exacerbates the losses that scab can cause.

Recent articles have reviewed the epidemiology, management, and history of scab outbreaks in the United States, Canada, Europe, Asia, and South America

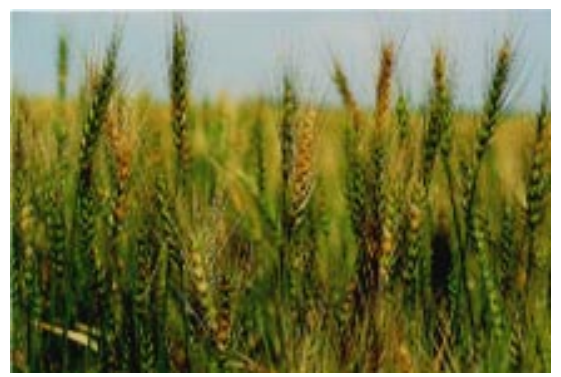

Fig. 1. Field symptoms of scab in hard red spring wheat. Entire head infections or portions of heads infected are visible as prematurely whitened glumes and awns.
$(5,40,45,48)$. As these papers indicate, numerous research and survey reports have described the worldwide occurrence and epidemic levels of scab during the past century. Yield loss reports have not always been based on replicated research trials, but extensive surveys of producers' fields have provided assessments of head blighting severity, which were translated into yield loss estimates. In the United States, scab was found in 31 of 40 states surveyed in 1917 , with losses estimated at 288,000 metric tons (10.6 million bushels), primarily in Ohio, Indiana, and Illinois (4). Scab caused an estimated loss of 2.18 million metric tons ( 80 million bushels) of winter and spring wheat throughout the United States in 1919 (14). Extensive field surveys

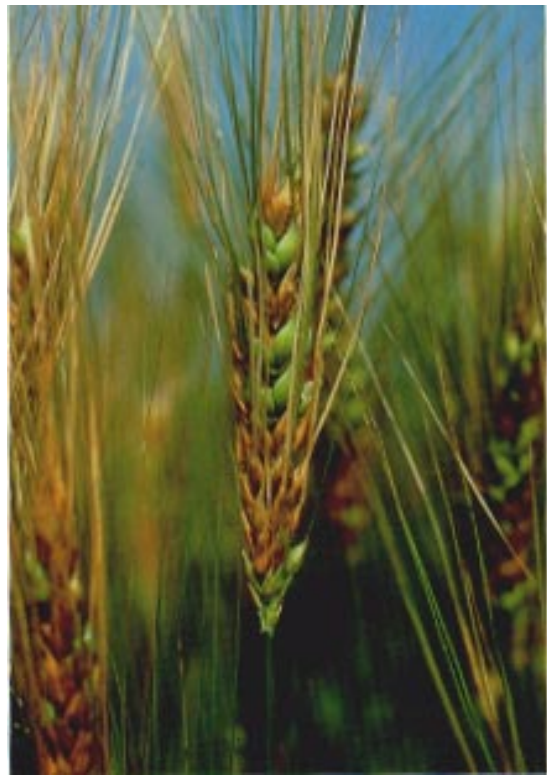

Fig. 2. Field symptoms of scab in spring barley. Discolored florets are symptomatic of scab infection. (courtesy Brian Steffenson, Department of Plant Pathology, North Dakota State University) 
showed additional large yield losses from 1928 to 1937 (15). In the 1980s, cool, wet weather in May and June led to epidemics in parts of Kansas (58), Nebraska, Missouri, Oklahoma, Iowa, southern Illinois (10), Indiana (44), and New York (9). In 1982 , scab caused an estimated $4 \%$ reduction in total United States wheat production, or more than 2.72 million metric tons (100 million bushels) (10).

Scab infections have been reported worldwide from wherever cereal crops are grown. Scab is endemic in China, the world's largest producer of wheat, where losses in excess of 1 million metric tons (about 38 million bushels) have been reported (53). The severe losses caused by scab in barley in South Korea in 1963 threatened some of the population with starvation (52). Argentinean epidemics affecting durum wheat occurred in the 1960s, 1970s, and 1980s (36). Epidemics in Canada and Japan also have been severe, resulting in extensive studies on the epidemiology and control of the disease $(38,48,60)$.

This article will describe economic and social impacts from some of the most recent scab outbreaks in North America, the causes leading to these outbreaks, and how scientists, producers, agencies, and industry are collaborating anew to develop effective strategies for managing scab. Although scab has been common, severe, and well documented in the past, recent epidemics have resulted in increased concern, greater public interest, and expanded research efforts.

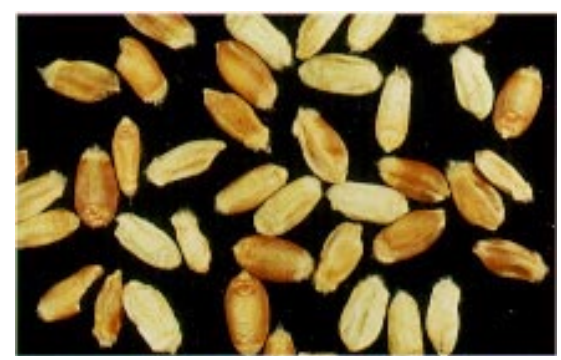

Fig. 3. Scabby "tombstone" kernels mixed with healthy hard red spring wheat kernels. (courtesy Jim Miller, U.S. Department of Agriculture, Fargo, ND)

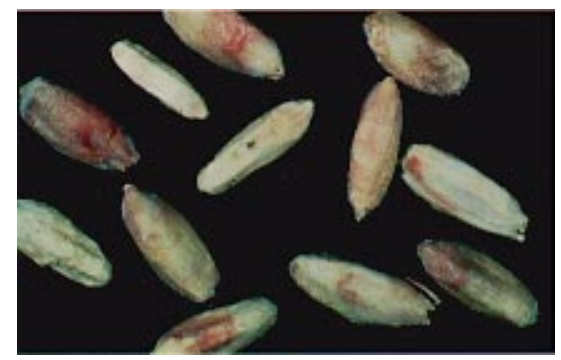

Fig. 4. Scabby durum kernels showing pinkish discoloration and chalky appearance. (courtesy Jim Miller, U.S. Department of Agriculture, Fargo, ND)

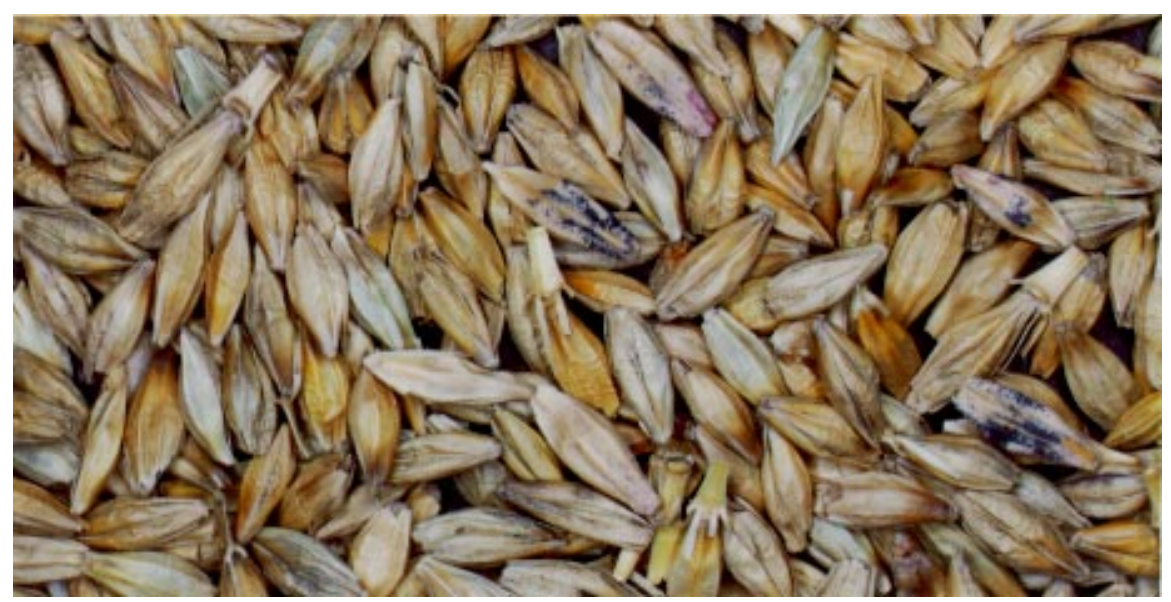

Fig. 5. Scabby barley kernels. Some show pinkish discoloration, others show blueblack perithecia of Gibberella zeae, the teleomorph of Fusarium graminearum. (courtesy Paul Schwarz, Cereal Science Department, North Dakota State University)

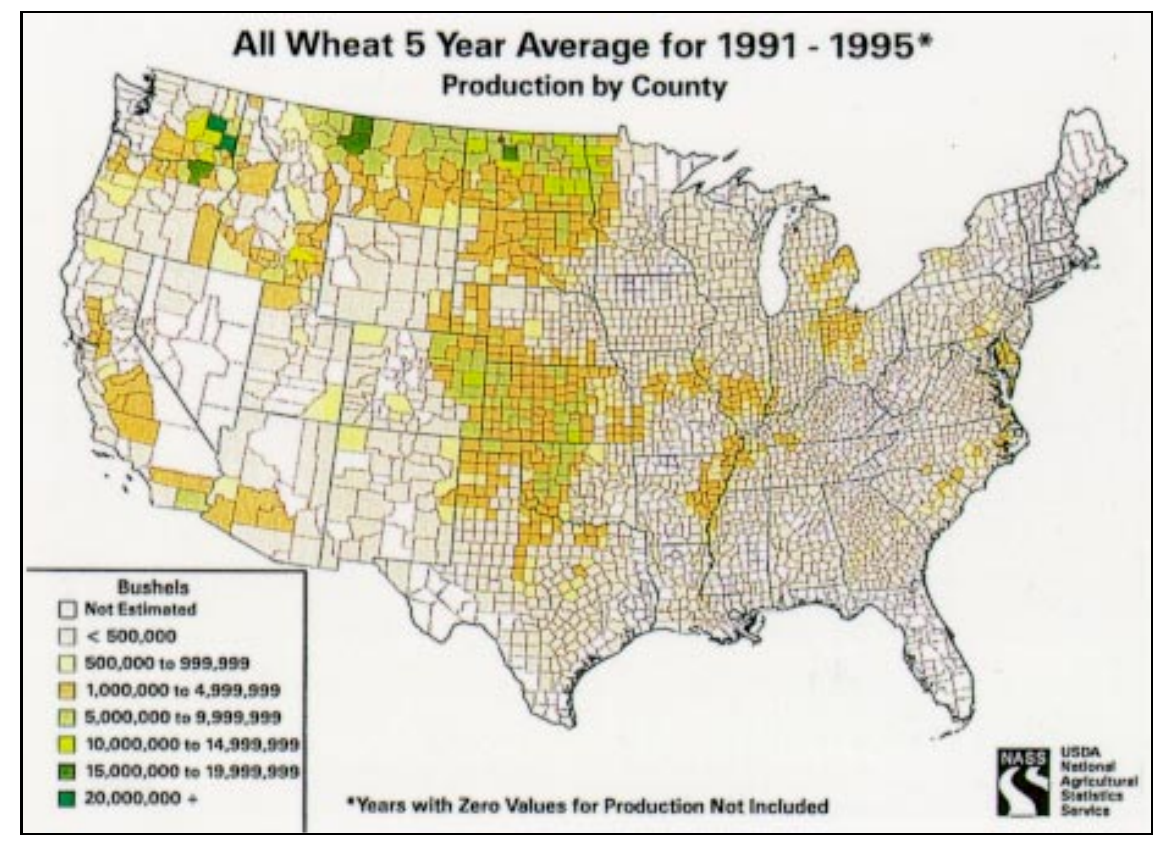

Fig. 6. Average wheat production per county in the United States, 1991 to 1995. Eastern half is primarily soft red winter wheat production and some white winter wheat (flour used for cookies, biscuits, cake mixes, cereals); western half is primarily hard red winter, hard red spring, and durum wheats, plus some white winter wheats (flour used in bread, pasta, cereals, noodles).

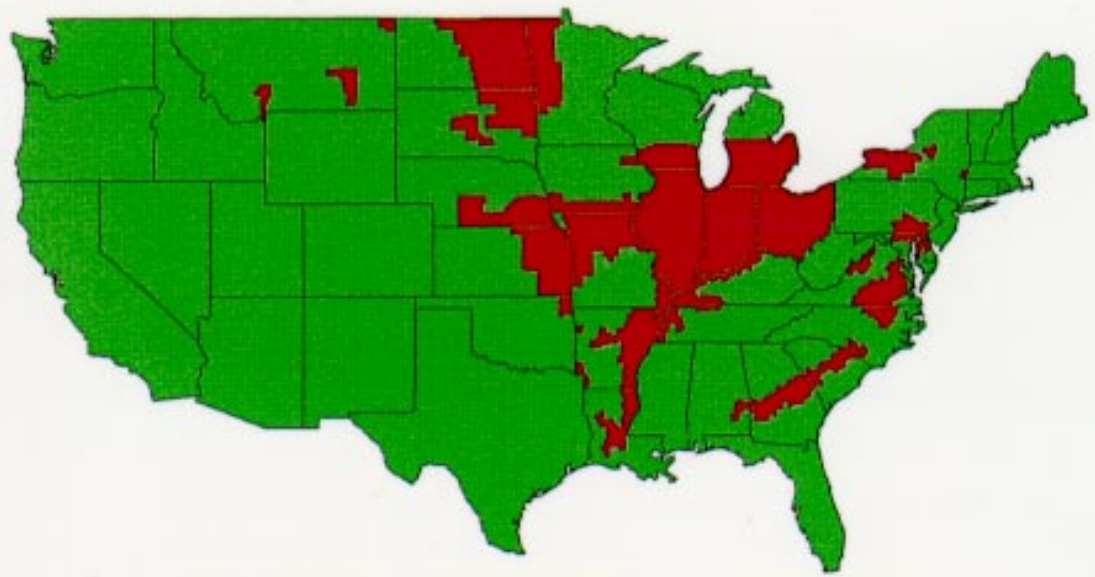

Fig. 7. Reported major outbreaks of scab on wheat and barley, United States, 1991 to 1996. (compiled from information provided by scientists who responded to a questionnaire) 


\section{Re-emerging Disease}

1991 to 1996 epidemics in the United States and Canada. Wheat production in the United States covers about 29.1 million hectares (72 million acres) each year (Fig. 6 ), with hectarage and production surpassed only by corn. Various classes of winter and spring wheats are grown, each used for specific milling or baking purposes such as bread, pasta, cookies, biscuits, noodles, cereals, and cake flour. Since 1991, scab outbreaks of varying intensity have been common and widespread across much of the eastern half of the United States, affecting yield and quality of wheat produced (Fig. 7). The locations of the recent scab outbreaks in wheat in the United States are reminiscent of those from 1928 to 1937 (Fig. 8), as described by Dickson (15). Historically, many of the outbreaks have been in areas of soft red winter wheat production, areas with high moisture (>500 $\mathrm{mm}$ rainfall) and abundant corn culture. But historic and recent epidemics indicate that when rainfall is above average, hard red winter and spring grain production areas of the eastern portions of the Great Plains (rainfall generally $<500 \mathrm{~mm}$ ) may also experience severe scab outbreaks.

The climatic conditions in the soft red winter wheat areas of the midwestern, southeastern, and mid-Atlantic states in 1991 favored development of scab and leaf diseases, with production dropping by about $25 \%$ or 2.72 million metric tons (100 million bushels) across 11 states and 6.1 million hectares (15 million acres) (24). In Arkansas, scab infection was the primary cause of average wheat yields dropping to $1.91 \mathrm{kl} / \mathrm{ha}(22 \mathrm{bu} / \mathrm{ac})$ compared with the previous 5 -year average of $3.73 \mathrm{kl} / \mathrm{ha}(42.8$ bu/ac) (34). Localized epidemics of scab also occurred in the upper Midwest in 1991, including areas of hard red spring wheat production in west central Minnesota (12) and in southeastern and east central North Dakota (29). In 1992, field surveys in Manitoba indicated an increased incidence of Fusarium head blight, with $25 \%$ of wheat fields surveyed having scab severities of $10 \%$ or greater (60). Illinois (26), Kansas (3), and Nebraska (54) reported significant levels of scab in eastern portions of their states in 1995.

In 1996, scab shook the soft red and soft white winter wheat trade, with epidemics in Iowa (37), Arkansas, Louisiana, Ohio, Indiana, Illinois, Wisconsin, Michigan, and New York, as well as in Ontario, Canada. The hardest-hit states were Illinois, Indiana, Michigan, and Ohio. For example, wheat producers in Ohio lost an estimated $\$ 100$ million in 1996 alone because of reduced yield, lower price received for remaining bushels, and cost of cleaning grain to achieve seed quality (P. Lipps, Ohio State University, personal communication). Wheat producers in both Illinois and Indiana suffered about a \$38 million loss in 1996 because of yield losses and price discounts due to scab (G. Shaner, Purdue University, personal communication). In Michigan, approximately one-half of the 1996 wheat crop was lost to scab, and the combination of reduced bushels and reduced quality resulted in an estimated \$56 million loss (P. Hart, Michigan State University, personal communication). Millers in these states paid high transportation costs to get unaffected grain and spent considerable resources in vomitoxin testing. Localized epidemics also occurred in 1996 in areas of north central and northeastern North Dakota and in southern Manitoba.

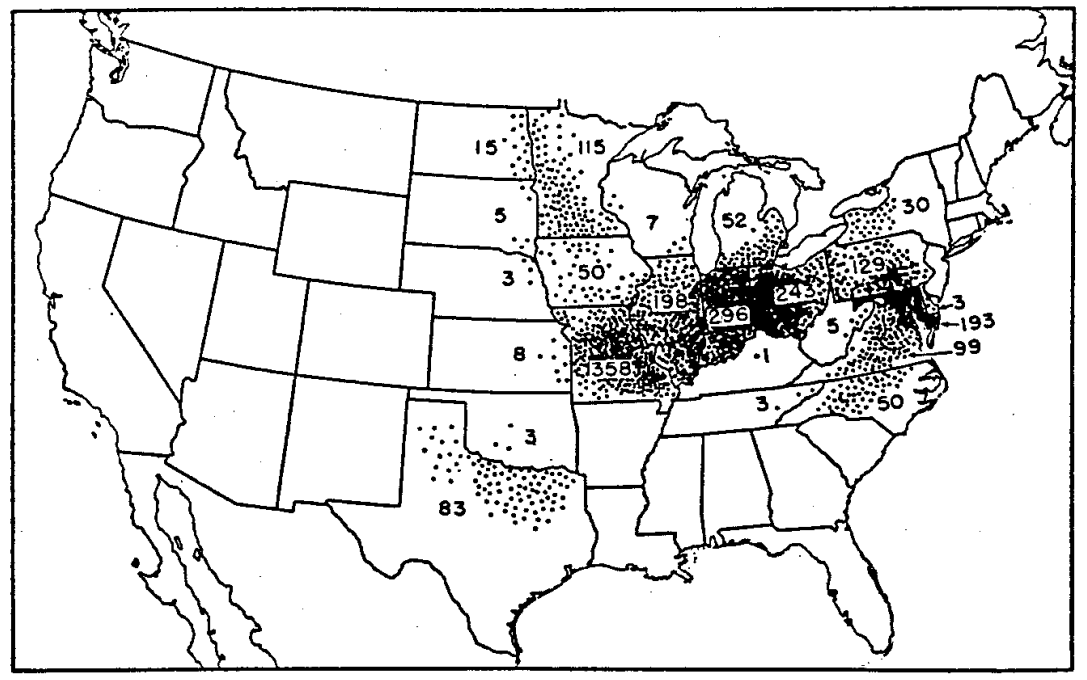

Fig. 8. Estimated average annual loss in bushels of wheat due to scab from 1928 to 1937, based on estimates by the Division of Mycology and Disease Survey, Bureau of Plant Industry, U.S. Department of Agriculture, and by annual scab surveys (15). Each dot $=1,000$ bushel loss. Figures indicate the average annual loss in 1,000 bushels for each state.

In addition to the above epidemics from 1991 to 1996 , scab devastated a large portion of the spring wheat and barley growing regions of North America in 1993 and 1994. An account of the 1993 epidemic follows, serving as an example of scab's potential to cause tremendous financial and human hardship. Following that account are descriptions of factors contributing to recent scab epidemics and of worldwide cooperative efforts to find answers for managing scab.

1993 epidemic: One region's ordeal. The tri-state areas of Minnesota, North Dakota, and South Dakota, and the Canadian prairie province of Manitoba produce hard red spring wheat, durum wheat, and spring barley. In 1993, scab struck this region (Fig. 9), an area traditionally near the top in North America in production of all wheat and malting barley $(6,7)$. Yield and quality losses caused producers of this region to suffer an estimated $\$ 1$ billion loss (11), making it one of the greatest losses due to any plant disease in North America in a single year. Bushel losses were much greater than that recorded for any previous

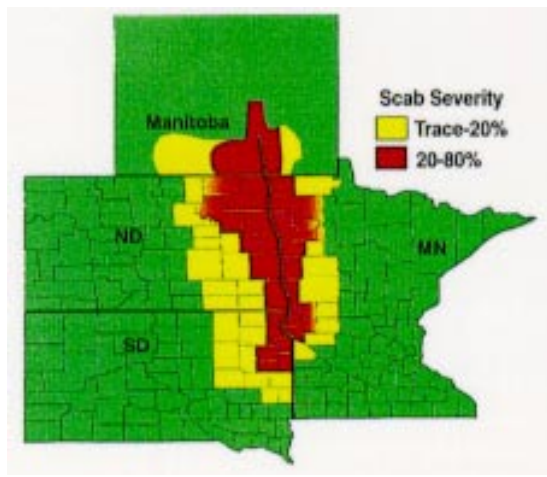

Fig. 9. Area and intensity of 1993 scab outbreak in hard red spring wheat, durum, and barley, Minnesota (MN), North Dakota (ND), South Dakota (SD), and Manitoba.

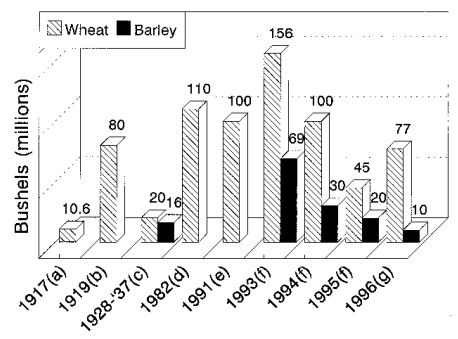

Fig. 10. Estimated wheat and barley losses (in million bushels) due to scab, United States, 1917 to 1996. Losses may have occurred in other years but were not recorded. a = Atanasoff 1920; b = Dickson 1929; c = Dickson 1942; d = Boosalis 1983; e = Kephart 1991; $f=$ losses in North Dakota, Minnesota, and South Dakota as estimated by authors; $\mathbf{g}=$ personal communications (see Acknowledgments). 
epidemic of scab in the United States (Fig. 10), and an estimated 4.0 million hectares (10 million acres) were affected.

Yield losses. Yields of wheat and barley plummeted in affected areas. For example, in northeastern North Dakota, average wheat yields dropped $45 \%$, from more than $49 \mathrm{bu} /$ harvested acre in 1992 to an average of 26.4 bu/harvested acre in 1993 (Fig. 11). Yield losses were estimated at 95 million bushels in North Dakota, 43 million bushels in Minnesota, and 18 million bushels in South Dakota. In Manitoba, scab caused an additional loss of 20 million bushels, for a total estimated wheat yield loss in the region of 176 million bushels (about 4.8 million metric tons) worth $\$ 704$ million. Barley losses were estimated at 56 million bushels in North Dakota, 12 million bushels in Minnesota and 1.6 million bushels in South Dakota, or a total of 69.6 million bushels (about 1.6 million metric tons) worth approximately $\$ 122$ million. In northeast North Dakota, for example, barley yields dropped from $75 \mathrm{bu} / \mathrm{ac}$ in 1992 to $45 \mathrm{bu} / \mathrm{ac}$ in 1993 (Fig. 12).

Yield losses due to scab were estimated or measured using field surveys by state and regional extension plant pathologists, by state departments of agriculture, and by county extension agents $(6,12,17,19,23,32)$. The survey estimates correlated highly with each state's Agricultural Statistical Services yield estimates after harvest $(1,7,20)$ and with yields from variety trials in the region. Field surveyors visually estimated number of heads infected (incidence) and amount of head infected (severity) (46). Incidence and head severity ranged from 5 to $80 \%$.

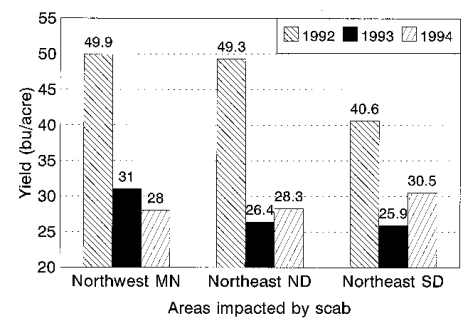

Fig. 11. Wheat yield comparisons in scab-affected areas: 1992 (no scab) versus 1993 and 1994 (severe scab).

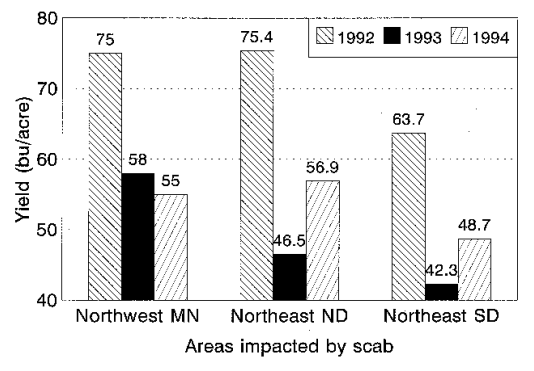

Fig. 12. Barley yield comparisons in scab-affected areas: 1992 (no scab) versus 1993 and 1994 (severe scab).
Quality losses. In addition to yield losses, the remaining harvested grain was low in test weight, high in percent damage due to scabby kernels, and high in vomitoxin content. Examination of over 1,000 field samples from eastern North Dakota revealed test weights as low as $44 \mathrm{lb} / \mathrm{bu}$, scabby kernel contents as high as $70 \%$, and vomitoxin levels as high as $44 \mathrm{ppm}$ (47). Similar quality problems also were observed in Minnesota (12) and in South Dakota (50). The 1993 regional quality report for wheat (35) indicated that in affected crop reporting districts, average test weights were well below that required for number one dark northern spring wheat, and percent damage was well above the level allowed for this top wheat class (Table 1). The minimum standard required for number one dark northern spring wheat was $58 \mathrm{lb} / \mathrm{bu}$, while the maximum percent damaged kernels allowed in 1993 was $2.0 \%$. Scabby or tombstone kernels are included in damage.

Vomitoxin discounts, wheat. The scab infection in the 1993 crops resulted in high concentrations of vomitoxin, which further reduced marketability and price. Until the fall of 1993, the U.S. Food and Drug Administration (FDA) had "levels of concern" for vomitoxin that included a guideline of $2 \mathrm{ppm}$ in raw grain. Average vomitoxin content in 1993 was well above this guideline in most areas (35). This forced the milling industry to seek scab-free wheat for blending and mixing purposes. The FDA tested for vomitoxin content among 1993 harvested wheat and barley samples across the United States (39). The Federal Grain Inspection Service (FGIS) assisted the FDA in providing representative samples from wheat- and barley-growing regions. FDA results in wheat indicated an average vomitoxin content of $4.7 \mathrm{ppm}$ across Minnesota (94 samples), $2.7 \mathrm{ppm}$ across North Dakota (62 samples), and 3.7 ppm across South Dakota (37 samples), while Kansas averaged 1.3 ppm (73 samples). Vomitoxin levels also averaged above $2 \mathrm{ppm}$ in several other states, but the sample size was much lower. These results were in contrast to 1991, when Illinois and Missouri averaged vomitoxin contents between 4 and $5 \mathrm{ppm}$, and Minnesota, North Dakota, and South Dakota levels were below 1 ppm (39).

Following the FDA analysis of vomitoxin levels in the 1993 crop, the "level of concern" for raw grain was dropped, but the guideline of " $1 \mathrm{ppm}$ for finished flour products" was maintained. The change in the FDA levels of concern for vomitoxin in the fall of 1993 shifted the consequences of vomitoxin contamination from the buying point to the marketplace.

The price of spring wheat on the Minneapolis grain exchange in the fall of 1993 reflected the extent of damage and vomitoxin levels (22) (Table 2). A number one milling quality, dark northern spring wheat was receiving $\$ 5.36 / \mathrm{bu}$, but if any vomitoxin was detected, the price was reduced by 96 cents. If the damage was high and the test weight was low, then the grade dropped to terminal grade (i.e., a grade below the top number one dark northern spring grade), and large additional discounts were given for the presence of vomitoxin. In truth, many producers had to sell at animal feed prices and were penal-

Table 1. 1993 hard red spring wheat survey, grading information for areas affected by scab (35)

\begin{tabular}{lccc}
\hline Affected area & Test weight $(\mathbf{l b} / \mathbf{b u})$ & ${\text { Damage }(\boldsymbol{\%})^{\mathbf{a}}}$ & Grade $^{\mathbf{b}}$ \\
\hline NW Minnesota & 56.1 & 4.6 & $3 \mathrm{DNS}$ \\
NE N. Dakota & 56.1 & 3.2 & $3 \mathrm{NS}$ \\
EC N. Dakota & 56.5 & 2.8 & $3 \mathrm{NS}$ \\
NE S. Dakota & 57.2 & 5.8 & $3 \mathrm{NS}$ \\
Regional avg. 1993 & 58.2 & 2.0 & 2 DNS \\
Regional avg. 1992 & 60.3 & 1.1 & 1 DNS \\
\hline
\end{tabular}

a Scabby kernels included in damage.

b DNS = dark northern spring wheat, 1 DNS = highest grade; NS = northern spring; 3 NS = lowest grade; test weight + damage + color influence grade.

${ }^{c}$ Regional average includes higher quality grain from less severely impacted districts within the three states.

Table 2. Base prices and vomitoxin discounts for hard red spring wheat, Minneapolis Grain Exchange (22)

\begin{tabular}{|c|c|c|c|c|}
\hline Market/contract ${ }^{\mathrm{a}}$ & $\begin{array}{l}1993 \text { contract } \\
\text { price }(\$ / b u)\end{array}$ & $\begin{array}{l}1993 \text { vomitoxin } \\
\text { discount }(\$ / b u)\end{array}$ & $\begin{array}{l}1994 \text { contract } \\
\text { price }(\$ / b u)\end{array}$ & $\begin{array}{l}1994 \text { vomitoxin } \\
\text { discount }(\$ / b u)\end{array}$ \\
\hline Milling & 5.36 & 0.96 & 4.50 & 0.25 \\
\hline Terminal, 2 ppm & 5.05 & 0.65 & 4.30 & 0.05 \\
\hline Terminal, $6 \mathrm{ppm}$ & 4.40 & 1.59 & 4.25 & 1.20 \\
\hline Feed & 2.81 & $N A^{b}$ & 3.05 & NA \\
\hline
\end{tabular}

${ }^{\text {a }}$ Milling $=$ highest grade or $1 \mathrm{DNS}$; terminal $=$ grades below $1 \mathrm{DNS}$.

${ }^{\mathrm{b}} \mathrm{NA}=$ not applicable 
ized with huge discounts. Wheat producers lost an estimated $\$ 86$ million due to vomitoxin discounts alone in 1993 (22). By 1994, familiarity with the disease and vomitoxin, plus increased supplies of clean wheat available for blending, resulted in somewhat smaller discounts based on vomitoxin levels. Net revenue per acre is never large for wheat producers in the northern Great Plains, but the yield and quality losses due to scab in 1993, and again in 1994, resulted in net losses (Fig. 13).

Vomitoxin discounts, barley. Average quality parameters for malting barley in the tri-state region were sufficiently good for malting grade in 1993, but vomitoxin levels in barley were high $(6,42)$. FDA tests found an average of $5.5 \mathrm{ppm}$ in samples from Minnesota and $4.8 \mathrm{ppm}$ in samples from North Dakota, with a range of 0 to 28 ppm (39). The high levels of vomitoxin in barley were a concern for the malting, brewing, and feed industry. The major buyers of malting barley adopted a standard of less than $0.5 \mathrm{ppm}$ in purchased grain, a standard that severely impacted barley growers in the affected region. The average barley price received by growers in affected areas was $\$ 0.25$ to $\$ 0.30$ per bu less than that received for malting barley (6).

Tough harvesting-marketing-end-use decisions. Producer decisions: Initially, many wheat and barley producers had to decide whether their crop was worth harvesting. Evaluations of fields in conjunction with Federal Crop Insurance representatives and with Farm Service Agency (formerly ASCS) agents led to decisions to either destroy the crop in the field or to try to salvage some yield. Many fields were not worth harvesting, based on near-zero yield potential. Approximately $18 \%$ of the wheat acreage in northwestern Minnesota was not harvested (1), and much of this acreage was eventually burned to destroy the residue. A Minnesota producer, Jerry Krueger, knew what was left of his 2,000 acres of wheat wasn't worth harvesting, but he still struggled emotionally with the decision. "I wasted my year, my family's work, my seed, my fertilizer... It's all down the tubes" (41).

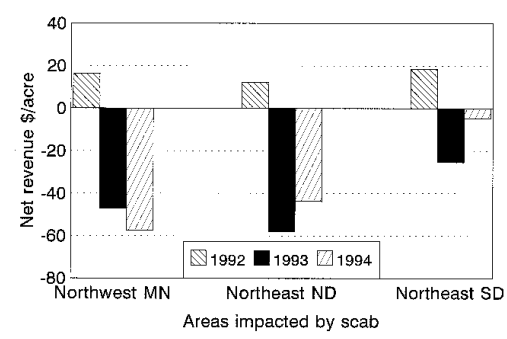

Fig. 13. Revenue per harvested acre, 1992 to 1994, for spring wheat producers in north central states affected by scab.
Producers who did harvest had to make tough decisions on whether to harvest as much grain as possible or turn up the fan speed on the combine to remove as many light, infected kernels as possible. Harvest was made doubly difficult because of the excessive soil moisture conditions that also accompanied harvest. Also, producers had to decide whether to try to sell their grain immediately, hold it and try to clean it with a gravity table to improve grade, or find alternative uses for severely infected grain, such as blending for feed or selling to alcohol plants. Producers who sold their grain immediately after harvest suffered the lowest prices, because the market was depressed.

Elevator quandaries: Elevator operators had a difficult time deciding whether to accept damaged grain, because the large cereal buyers were uncertain of what they would accept. Elevator operators did not want to ship a carload to Minneapolis and have it rejected, nor did a buyer want to ship a railroad car to port and have it fail to meet standards. Uncertainty about vomitoxin testing protocols and questions about the accuracy of testing procedures added to the initial confusion about vomitoxin levels and requirements for testing. By midautumn, establishment of and training with the ELISA quick test increased the accuracy and reliability of the vomitoxin testing procedures, and the test became an industry standard at the elevator. Overall, the elevator industry was severely affected because of the small amount of grain being delivered and the added cost of vomitoxin analysis.

Market reactions: Once the FDA relaxed the level of concern for raw grain, markets stabilized, but the prices received by growers were much lower than the market price received in other regions because of the vomitoxin discounts and poorer quality (22). Ultimately, the epidemic resulted in higher wheat prices nationwide because of reduced supplies. The average price for good quality wheat in the region in 1993 was the highest $(\$ 4.03 / \mathrm{bu})$ since the 1988 drought $(\$ 4.02 / \mathrm{bu})$ and the highest in the previous 10 years (7). However, the farmers in the affected region had little to sell.

Health concerns: Great concern existed among grain and livestock producers, millers-handlers, brewers, and the general public, about the safety of affected grain for use as food, feed, or for bedding purposes. Consumers were concerned about the impact of this disease on the quality of their bread, cookies, and other wheat products. Calls were received on the safety of ready-to-eat cereals, how much vomiting would ensue, and also on air-quality issues. Although the impact of ingesting vomitoxin is not well documented for humans, the literature provided substantial evidence about negative impacts on swine and on some other nonruminant animals. Scabby wheat was analyzed for milling qualities, and some adverse effects on bread making were known (35). Durum and spring wheat millers had to make decisions on purchasing any of this grain, and on how much unaffected grain would be necessary for blending purposes to achieve the processed grain guideline of $1 \mathrm{ppm}$ or less of vomitoxin content. Barley malters did not want scabby barley; the water-soluble toxin is extremely heat stable and the presence of the fungus in malt may cause gushing of the beer (43). Large malting plants in the

\section{Diseases ravage wheat Grain/ Mreat scab

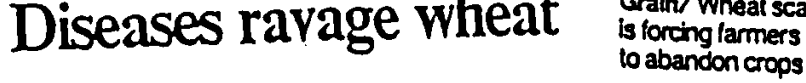

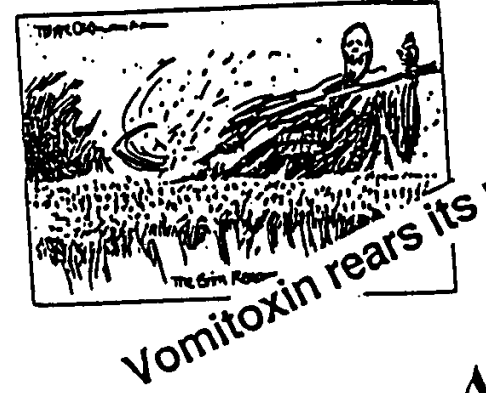

Crop disease, flood damage will be felt in the N.D. economy
Farmers panic zuined whe $a_{\text {fild }}$ smaller than expected
Fields of disappointment 
region spent millions of additional dollars procuring enough noncontaminated grain for their malting production.

Sociological impacts. Producers and rural communities in affected regions suffered greatly in 1993 from the economic uncertainties caused by scab. At harvest, producers were surprised and alarmed to find severe scab infections and empty heads. Although preliminary warnings of scab infection had been provided to growers in late July via extension pest reports and news releases, the producers and the millers had been lulled by seemingly lush green crops and early predictions of another year of record yields. But when the magnitude of the epidemic became apparent, past histories and experiences with the disease were not adequate to handle its overwhelming nature. One of the largest cereal-producing areas in the world was in turmoil. Headlines from newspapers in the region and the nation during the late summer and fall of 1993 reflect despair, panic, and frustration (Fig. 14). Foreclosures and bankruptcies led to a ripple effect in small rural communities. The Wall Street Journal described the effect on the small town of Webster, South Dakota (population 2,417): "Car sales dropped $15 \%$ at Mid-West Motors as a salmon-colored mold spread through the flowering wheat fields. It was the final straw for the locally owned farmequipment dealership, and merchants in Webster fretted that farm families had less reason to shop their Main Street" (25). The North Dakota, Minnesota, and South Dakota extension services established task forces to aid producers and businesses through some of the tough economic and psychological crises. The human experiences that resulted from this epidemic are difficult to summarize. They did, however, leave indelible marks.

Recurrence. Scab recurred in parts of the spring wheat and barley areas in 1994 through 1996 (18,23,31). In northwest Minnesota, scab losses in 1994 exceeded the 1993 losses (Figs. 11 to 13). Localized epidemics occurred in 1995 and 1996, with yield losses and price discounts resulting in an estimated $\$ 200$ million loss in North Dakota in 1996.

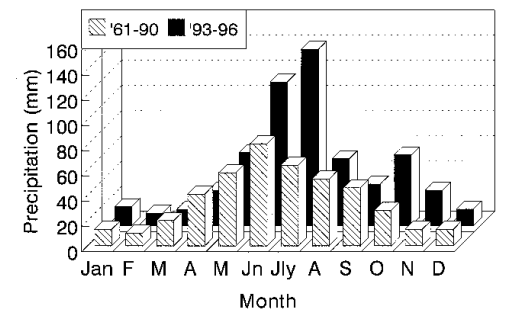

Fig. 15. Comparison of precipitation patterns in years of scab outbreaks versus long-term (30 year) normal precipitation, North Dakota (7).
Weather. The very wet weather during 1993 led to severe flooding and associated problems in many areas of the United States. Areas of North Dakota, Minnesota, and South Dakota affected by scab in 1993 typically have relatively dry and cool climates, with annual rainfall ranging from $355 \mathrm{~mm}$ in the western edges to 500 to 635 $\mathrm{mm}$ in the eastern portions. Traditionally, the greatest precipitation occurs in June, based on the 30-year average from 1961 to $1990(7,16)$ (Fig. 15), a time when springplanted small grains are in leaf development stages. Spring grains in this region flower and develop kernels in July, a month generally characterized by lower rainfall and higher temperatures than June. But in 1993, July was characterized by some of the highest rainfall totals on record (16). Rainfalls averaged from 250 to $600 \%$ above normal in eastern North Dakota, northeastern and west central Minnesota, and northeastern South Dakota. In July 1993, measurable rainfall was recorded at Crookston, Minnesota, on 26 of the 31 days (55). Disease development was favored by moist weather lasting from 4 to 6 weeks, a time in which almost all of the wheat crop flowered and began grain fill, and when the barley kernels were filling. Conditions also were favorable for infection in Manitoba (19).

Above-normal precipitation in July in recent years (7) (Fig. 15) has contributed to recurring localized epidemics in North Dakota and Minnesota. Similarly, high rainfall and high soil moisture levels in May or early June have contributed to epidemics of scab in winter wheat growing areas in recent years $(3,9,24,26,37,54)$.

Other factors. Although environment is important in the development of scab epidemics, other factors contribute, including high proportions of minimum tillage, high percentages of cultivated acres planted to susceptible host crops, and short rotation intervals between susceptible crops. These conditions occurred in 1993 and 1994 in the spring wheat and barley regions (23) and are similar to those reported favoring scab epidemics in other countries (28).

The causal fungus survives in the residue of host crops such as wheat, barley, and corn. Nationwide, the increase in con-
Why is Scab So Severe Again? servation tillage within the last 10 years has been significant (2). Conservation tillage includes mulch or minimum till, notill, and ridge till. Since corn is a host and an important reservoir of the scab fungus $(48,59)$, an increase in conservation tillage acres, with possible concomitant increase in presence of infected corn residue on the epidemics in the soft red winter areas. Acreage of conservation tillage corn overtook acreage of conventional tillage in 1993. States with the greatest no-till corn acreages are Iowa, Illinois, Nebraska, Indiana, and Ohio (2). In states such as North Dakota, where wheat is the primary crop, wheat residue on the surface has led to increased risk. North Dakota ranks among the top five states in mulch-till acres, and the acreage of no-till wheat has increased substantially in recent years (2).

Another factor possibly leading to increased levels of scab in recent years has been the U.S. Department of Agriculture's farm program. In states such as North Dakota, Minnesota, and South Dakota, this farm program encouraged producers to maintain high acreage of wheat and discouraged crop rotation because deficiency payments were tied to enrollment in the wheat program. For example, North Dakota had $96 \%$ of its 4.9 million hectares (12.1 million acres) of wheat enrolled in the Farm Program in 1993, Minnesota had $88 \%$, and South Dakota had 93\% (USDA report on acres in farm program, 1994, personal communication from North $\mathrm{Da}$ kota Farm Service Agency) (Table 3). Also, in 1991, farmers supported legislation to eliminate set-aside programs, which further limited the practice of crop rotation in wheat-intensive areas.

\section{Managing Scab The Search for Answers}

We cannot control the weather; we cannot expect a large shift in tillage trends; and we will always grow large amounts of wheat and corn in the United States. We must search for other solutions for managing scab.

Breeding for resistance. In 1929, J. J. Christiansen, E. C. Stakman, and F. R. Immer (13) said that "the only effective method of controlling wheat scab (Fusarsoil surface, may be contributing to recent

Table 3. Percent acreage enrolled in farm program in North Dakota, Minnesota, and South Dakota, 1993 (USDA Report on Acres in Farm Program, 1994, personal communication from North Dakota Farm Service Agency)

\begin{tabular}{lccc}
\hline State & Crop & $\begin{array}{c}\text { Base acres } \\
\text { (millions) }\end{array}$ & $\begin{array}{c}\text { Enrolled } \\
(\boldsymbol{\%})\end{array}$ \\
\hline North Dakota & Wheat & 12.1 & 96 \\
& Barley & 3.2 & 92 \\
Minnesota & Wheat & 3.2 & 88 \\
& Barley & 0.86 & 86 \\
South Dakota & Wheat & 4.5 & 93 \\
& Barley & 0.78 & 79 \\
\hline
\end{tabular}


ium head blight) is to grow resistant varieties." Not much has changed since then, but we may have better ways to obtain those resistant varieties today: new sources of resistance have been identified $(5,11,27,51,53)$; a better understanding of the kinds of resistance exists (33); the molecular tools for incorporating resistance are being developed (5); improved collaboration in the exchange and evaluation of breeding materials has occurred; and hopefully, a longer term commitment to research funding has evolved.

In the midst and aftermath of the 1993 scab epidemic, plant breeders and plant pathologists associated with agricultural universities, government agencies, or private companies screened existing hard red spring wheat, durum wheat, and barley cultivars in the field and after harvest for scab severity, kernel characteristics, yield, test weight, and vomitoxin levels $(11,32,55)$. The widespread occurrence of the disease allowed evaluation of existing adapted cultivars to determine which had the most tolerance, and this information was widely disseminated to producers. Similar evaluations have been possible in soft red winter wheat areas $(5,27)$. Greenhouse evaluations of breeding lines, using challenge inoculations of mixtures of isolates of $F$. graminearum and other scab inducing species, provide additional information on cultivar and advanced line susceptibility. In 1994, Uniform Regional Scab Nurseries were established in Manitoba, Minnesota, North Dakota, and South Dakota to allow testing of public and private breeding materials across a number of locations and environments. At each nursery, mist irrigation and supplemental inoculum were provided to assure infection. The North Dakota State University barley breeding and pathology programs established an additional field nursery in southeastern China, near Shanghai, to evaluate lines under the endemic infection levels present in China.

Genetic materials for all classes of wheat and also for barley are coming from all over the world, from research programs that have identified sources of resistance $(5,11,21,33,36,40,45,51,53)$. In addition, interspecific crosses from other grass species also are being conducted. Of thousands of lines and crosses screened, much less than $1 \%$ have improved levels of resistance, and these lines then must be incorporated into cultivars that are adapted and have the yield and quality characteristics desired for the crop and region. Historically, breeders and pathologists have been able to identify and accumulate partial resistance to scab. The challenge for them is to develop effective screens, cooperatively standardize methods, and understand the inheritance of this partial resistance. Maintaining resistance in commercial wheats must not be at the expense of yield or quality. The alternative is that resistance will be discarded when environmental conditions become unfavorable for scab.

Cultural practices. Crop rotations are a key to reducing the risk of severe scab. Although all producers in affected regions in 1993 suffered some degree of scab, no matter what their rotation, subsequent questionnaires indicated that those who did not have corn or wheat as the previous crop had less severe scab (30). The value of crop rotations in reducing scab has been demonstrated $(4,14,15,23,30,38,40,48,49,59)$. The new "Freedom to Farm" Act in the United States may increase the flexibility of producers to try better crop rotations and alternative crops. Producers in the upper Great Plains certainly have new interest in crops such as carrot, crambe, canola, field peas, and lentils as alternatives to wheat and barley in their crop rotation sequence.

Although producers are interested in maintaining soil organic matter and soil moisture, those affected in the areas of heavier soils are looking at tillage rotation as an alternative to continuous no-till or minimum till. Previous and current studies are examining long-term effects of various tillage practices on residue and fungal survival.

Crop protection chemicals. We observed beneficial results from the use of seed treatment fungicides to limit damage caused by seedling blight, a potential problem when infected seed is planted. However, results with heading time application of fungicides to reduce scab have been variable $(28,34,40,57)$. Inconsistent success with heading treatments may occur in part because of lack of disease forecasting information. This includes incomplete knowledge about inoculum development and movement. Fungicide costs in relationship to return per acre is another limiting factor in the use of fungicides for scab management. Improved application technology and disease forecasting information may allow producers to effectively use fungicides in conjunction with other disease management strategies (28). In addition to standard fungicides, we and others (40) are evaluating biological agents for their activity against $F$. graminearum.

Networks of cooperation. Recent epidemics have fostered a worldwide sense of urgency and cooperation in finding answers to scab. In addition to regional nurseries and cooperative research projects in the north central region, scab forums have been held annually from 1993 to 1996 in Moorhead, Minnesota; Fargo, North Dakota; Brookings, South Dakota; and Winnipeg, Manitoba, respectively. These forums provided the opportunity for input from producers, industry, research, and extension personnel, and resulted in discussion of research projects, results, and needs. In addition, researchers from other affected areas across North America and Mexico also attended. Similar conferences were held in 1997 in Michigan and Ohio in response to the 1996 epidemic in that region. The 1993 scab epidemic led to establishment of the North Central Regional Research Committee in 1994 (NCR184), with chairmanship of the committee rotating among states. In October 1996, a discussion among 21 scientists from around the world working with scab was held at the CIMMYT headquarters in Mexico. An international seminar on Fusarium head blight and Fusarium mycotoxins will be held in the fall of 1997 in Szeged, Hungary. Today, Internet sources abound with information about this disease. Roy Wilcoxson, emeritus professor of plant pathology from the University of Minnesota, has collated a bibliography of all the known publications about this disease, available through the University of Minnesota Department of Plant Pathology, and he has compiled a list of references on chemical control of scab (57).

Research funding. At the first Regional Scab Forum, Roy Wilcoxson described the ebb and flow of scab research and its funding (56). As recent epidemics have created a greater public awareness of this disease and its potential severe impact, it is hoped that funding will be more long-term and more national in scope. The 1993 epidemics resulted in state legislative initiatives in North Dakota (\$357,000 over 2 years) and Minnesota ( $\$ 477,000$ for 1993). These funds have been used to hire a regional small grain specialist and additional technical support, as well as for expenses involved in winter nurseries, greenhouse screening, and vomitoxin testing. Additional funding also has been received from local crop improvement associations and from state wheat and barley producer organizations. The American Malting Barley Association also made substantial financial contributions to the barley breeding, pathology, and cereal science programs. While some state and regional funding for scab research was provided, additional research support is needed. A long-term commitment at the national level to sustain current breeding and pathology efforts is needed. Michigan State University organized a meeting in Chicago in March 1997, in which scientists from states of the north central region developed a cooperative proposal for securing federal funding for scab research.

Future outlook. What is the outlook for wheat and barley producers with regard to future scab epidemics? While there is still much to be learned about this disease and its management, we know that weather will play a significant role. Cultivars, rotations, tillage practices, fungicide use, and other factors also will affect the disease. In the short term, we will have scab. The question is, how much and where will it strike? As newspaper cartoonist Trygve Olson so aptly illustrated (Fig. 16), there is a concern about a worldwide food short- 


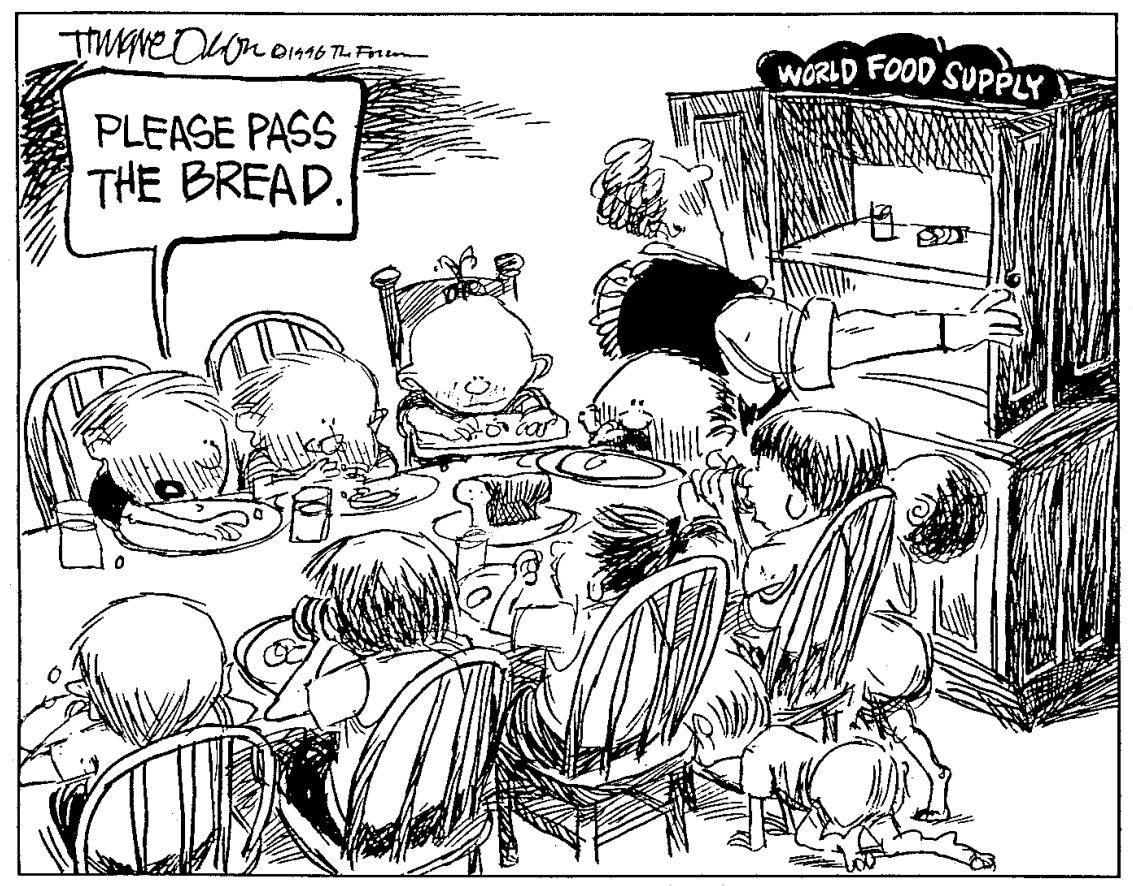

Fig. 16. Will wheat scab contribute to shortage of world food supply? Cartoon by Trygve Olson, May 6, 1996: THE FORUM (Fargo/Moorhead regional newspaper)

age. The cupboard should not be bare, nor should a disease such as scab contribute to such a shortage. We need to solve this problem so that wheat and barley producers worldwide can help provide a wholesome and abundant grain supply.

\section{Acknowledgments}

We thank the following scientists who responded to a questionnaire about recent scab outbreaks in their states: Gene Milus, Arkansas; Gary Bergstrom, New York; Laura Sweets, Missouri; Pat Hart, Michigan; John Watkins, Nebraska; Bob Bowden, Kansas; Clayton Hollier, Louisiana; Gary Munkvold, Iowa; Don Scott and Greg Shaner, Indiana; Walker Kirby, Illinois; Bob Hunger, Oklahoma; Craig Grau and Lorna Pieterek, Wisconsin; Gary Franc, Wyoming; Bill Brown, Colorado; and Jack Riesselman, Montana. Information about other states was derived from the 1991 VPI Technical Report (24). We thank the numerous collaborators who contributed in one way or another in the preparation of this manuscript, including those who provided personal communications, those who provided photos, and those colleagues who reviewed the manuscript.

\section{Literature Cited}

1. Anonymous. 1994. Minnesota Agricultural Statistics. Minn. Agric. Stat. Serv., St. Paul.

2. Anonymous. 1995. Conservation Impact 13(\#9). Conserv. Technol. Information Ctr. Newsl., West Lafayette, IN

3. Appel, J. A., and Bowden, R. L. 1995. Preliminary 1995 Kansas wheat disease loss estimates. Kansas Plant Disease Survey Report, August 4, 1995. Kansas Department of Agriculture, Topeka.

4. Atanasoff, D. 1920. Fusarium-blight (scab) of wheat and other cereals. J. Agric. Res. 20:132.

5. Bai, G., and Shaner, G. 1994. Scab of wheat: Prospects for control. Plant Dis. 78:760-766.

6. Barr, J., Salas, B., Schwarz, P., and Steffenson, B. 1996. Impact of Fusarium head blight infection on barley produced in the Upper Midwestern United States during 1993-1995.
(Abstr.) Am. Soc. Brewing Chem. Newsl. $56: 3$.

7. Beard, L., ed. 1996. North Dakota Agricultural Statistics. Vol. 65. North Dakota Agric. Statistical Serv., Fargo.

8. Bergstrom, G. C. 1993. Scab (Fusarium Head Blight). Pages 83-93 in: Seed-borne Diseases and Seed Health Testing of Wheat. S. B. Mathur and B. M. Cunfer, eds. Jordbrugsforlaget Publisher, Frederiksberg, Denmark.

9. Bergstrom, G. C., Kalb, D. W., Schilder, A. M. C., Cox, W. J., Harman, G. E., and Saminy, C. 1987. Assessment of the 1986 winter wheat scab epidemic in New York. (Abstr.) Phytopathology 77:1613.

10. Boosalis, M. G., Doupnik, B. L., Wysong, D. S., and Watkins, J. E. 1983. The wheat scab epidemic of 1982. Univ. Nebr. Farm, Ranch Home Quart. 29:7-9.

11. Busch, R. 1995. Breeding for scab resistance. Page 3 in: Proc. 1994 Regional Scab Forum Res. Conf. Minnesota Wheat Research and Promotion Council, Red Lake Falls

12. Cavanaugh, K. 1994. Scab in west central Minnesota. Pages 12-15 in: Proc. 1993 Regional Scab Forum. Minnesota Wheat Research and Promotion Council, Red Lake Falls.

13. Christensen, J. J., Stakman, E. C., and Immer, F. R. 1929. Susceptibility of wheat varieties and hybrids to fusarial head blight in Minnesota. Minn. Agric. Exp. Stn. Bull. 59.

14. Dickson, J. G. 1929. Scab of wheat and barley and its control. USDA Farmers' Bull. No. 1599:1-17.

15. Dickson, J. G. 1942. Scab of wheat and barley and its control. USDA Farmers' Bull. No. 1599 (revised): 1-22.

16. Enz, J. 1995. Climatic summary. Pages 228232 in: 1996 Crop Production Guide No. 6. N.D. State University Extension Service, Fargo.

17. Gallenberg, D. J. 1993. Wheat scab. South Dakota State Univ. Coop. Ext. Serv. Extension Extra. ExEx 8097. South Dakota State University, Brookings.

18. Gilbert, J., Tekauz, A., Kaethler, R., Mueller, E., and Kromer, U. 1995. Occurrence of Fusarium head blight in Manitoba in 1994.
Can. Plant Dis. Surv. 75:124-125.

19. Gilbert, J., Tekauz, A., Mueller, E., and Kromer, U. 1994. Occurrence of Fusarium head blight in Manitoba in 1993. Can. Plant Dis. Surv. 74:77.

20. Hamlin, W. G., and Noyes, S. 1996. S.D. Agric. Stat. Bull. No. 56. S.D. Agric. Stat Serv., Sioux Falls.

21. Ireta, M. J., and Gilchrist, L. 1994. Fusarium head scab of wheat. Wheat Special Report 21b. CIMMYT, Mexico, D. F

22. Johnson, D. D., Wilson, W. W., and Diersen, M. 1995. Quality uncertainty and grain merchandising risk: Vomitoxin in spring wheat. Agric. Econ. Rep. No. 333. North Dakota State University, Fargo.

23. Jones, R. K. 1994. Managing Fusarium head scab for 1995. Minn. Ext. Serv. Plant Pest Newsl. PPST17:100-102. Department of Plant Pathology, University of Minnesota, St. Paul.

24. Kephart, K. 1991. Climatic conditions and regional differences. Pages 5-10 in: Soft Red Winter Wheat Quality: Issues for Producers, Merchants, and Millers. E. Jones, ed. VPI Coop. Ext. Publ. 448-051. Virginia Polytechnic Institute, Blacksburg.

25. Kilman, S. 1993. "After the flood, midwest farmers reap their shrunken crops, those worth picking." Wall Street Journal. Oct. 21. pp. A1, A8.

26. Kirby, W. H. 1995. Wheat diseases. Ill. Coop. Ext. Serv. Pest Manage. Crop Devel. Bull. 15:166. University of Illinois, Champaign.

27. Lipps, P., and Johnston, A. L. 1996. Head scab reaction of selected winter wheat cultivars, breeding lines, and germplasm lines to Fusarium graminearum, 1995. Biol. Cult. Tests Control Plant Dis. 11:85.

28. Mauler-Machnik, A., and Zahn, K. 1994. Ear fusarioses in wheat - new findings on their epidemiology and control with Folicur (tebuconazole). Pflanzenschutz-Nachrichten Bayer 47:129-155.

29. McMullen, M. P. 1991. Head scab - losses, storage, marketing, disposal. N.D. State Univ. Ext. Serv. Crop Pest Rep. 14:1-2.

30. McMullen, M. P., and Luecke, J. L. 1996. Onfarm cropping system effects on Fusarium head blight (scab), 1995. N.D. State Univ. Ext. Rep. 29:1-7.

31. McMullen, M. P., and Nelson, D. R. 1995 Fusarium head blight and Septoria diseases of wheat severe in North Dakota, 1994. (Abstr.) Phytopathology 85:1045.

32. McMullen, M. P., and Stack, R. W. 1994 Vomitoxin levels in durum and hard red spring wheats infected with Fusarium head blight, 1993. Biol. Cult. Tests Control Plant Dis. 9:116.

33. Mesterhazy, A. 1995. Types and components of resistance to Fusarium head blight of wheat. Plant Breed. 114:377-386.

34. Milus, E. A., and Parsons, C. E. 1994 Evaluation of foliar fungicides for controlling Fusarium head blight of wheat. Plant Dis 78:697-699.

35. Moore, W. R., Helm, J. L., Olson, T. C., Nelson, R., and Puhr, D. 1993. The quality of the regional (Montana, North and South Dakota, Minnesota) 1993 hard red spring wheat (DNS) crop. Page 4 in: Hard Red Spring (DNS) Wheat 1993 Regional Quality Report. Cereal Science Department, North Dakota State University, Fargo.

36. Moschini, R. C., and Fortugno, C. 1996 Predicting wheat head blight incidence using models based on meteorological factors in Pergamino, Argentina. Eur. J. Plant Pathol. 102:211-218.

37. Munkvold, G. 1996. Outbreak of wheat scab Iowa State Univ. Integrated Crop Manage. Newsl. IC476(18):130.

38. Nisidako, Y. 1959. Studies on the wheat scab, 
caused by Gibberella zeae (Schw.) Petch, and its control. (English summary) Berichte Ohara Instituts 11:1-165.

39. Page, S. 1993. Food and Drug Administration's Perspective. Pages 80-83 in: Proc. 1993 Regional Scab Forum. Minnesota Wheat Research and Promotion Council, Red Lake Falls.

40. Parry, D. W., Jenkinson, P., and McLeod, L. 1995. Fusarium ear blight (scab) in small grain cereals - a review. Plant Pathol. 44:207238.

41. Schmickle, S. 1993. "To harvest or destroy crops? Disasters force tough choices on farms." Minneapolis Star-Tribune. Sept. 4. pp. 1A, 11-13A.

42. Schwarz, P. B., Casper, H. H., and Barr, J. M. 1995. Survey of the occurrence of deoxynivalenol (vomitoxin) in barley grown in Minnesota, North Dakota and South Dakota during 1993. Tech. Quart., MBAA 32(4):190-194.

43. Schwarz, P. B., Casper, H. H., and Beattie, S. 1995. Fate and development of naturally occurring Fusarium mycotoxins during malting and brewing. J. Am. Soc. Brew. Chem. 53(3):121-127.

44. Scott, D. H. 1986. Scab of wheat. Purdue Univ. Pest Manage. Newsl. 16:5-7.

45. Snijders, C. H. A. 1990. Fusarium head blight and mycotoxin contamination of wheat, a review. Neth. J. Plant Pathol. 96:187-198.
46. Stack, R. W., and McMullen, M. P. 1995. A visual scale to estimate severity of Fusarium head blight in wheat. N.D. State Univ. Ext. Publ. PP-1095.

47. Stack, R. W., McMullen, M. P., and Casper, H. 1995. Vomitoxin and visible scab in 1993 spring wheat in North Dakota and adjacent areas. (Abstr.) Can. J. Plant Pathol. 17:362.

48. Sutton, J. C. 1982. Epidemiology of wheat head blight and maize ear rot caused by Fusarium graminearum. Can. J. Plant Pathol. 4:195-209.

49. Teich, A. H., and Nelson, K. 1984. Survey of Fusarium head blight and possible effects of cultural practices in wheat fields in Lambton county in 1983. Can. Plant Dis. Surv. 64(1):11-13.

50. Turnipseed, B. 1993. Testing of scabby seed. Pages 38-41 in: Proc. 1993 Regional Scab Forum. Minnesota Wheat Research and Promotion Council, Red Lake Falls.

51. Van Ginkel, M., Van Der Schaar, W., Zhuping, Y., and Rajarm, S. 1996. Inheritance of resistance to scab in two wheat cultivars from Brazil and China. Plant Dis. 80:863-867.

52. Vestal, E. F. 1964. Barley scab in South Korea in 1963 and 1964. Plant Dis. Rep. 48:754-755.

53. Wang, Z.-Y., Yong, X.-N., and Xiao, Q.-P. 1982. The improvement of identification technique of scab resistance of wheat and the development of resistant sources. Sci. Agric.
Sin. 5:67-77.

54. Watkins, J. 1995. Head diseases prominent in wheat. Univ. Nebr. Crop Watch No. 95-15, June 30, 1995.

55. Wiersma, J. V., Peters, E. L., Hanson, M. A., Bourvette, R. J., and Busch, R. H. 1996. Fusarium head blight in hard red spring wheat: Cultivar responses to natural epidemics. Agron. J. 88:223-230.

56. Wilcoxson, R. D. 1993. Historical overview of scab research. Pages 1-5 in: Proc. 1993 Regional Scab Forum. Minnesota Wheat Research and Promotion Council, Red Lake Falls.

57. Wilcoxson, R. D. 1996. Fungicides for control of Fusarium head blight - a review. Minn. Agric. Exp. Stn. Pap. No. 22,507. University of Minnesota, St. Paul.

58. Willis, W. G. 1983. Kansas wheat scab situation in 1982. Pages 2-3 in: Scab and deoxynivalenol in the 1982 wheat crop. Kans. Agric. Exp. Stn. Prog. Rep. 440.

59. Windels, C. E and Kommedahl, T. 1984. Late-season colonization and survival of Fusarium graminearum Group II in cornstalks in Minnesota. Plant Dis. 68:791-793.

60. Wong, L. S. L., Tekauz, A., Leisle, D., Abramson, D., and McKenzie, R. I. H. 1992 Prevalence, distribution, and importance of Fusarium head blight in wheat in Manitoba. Can. J. Plant Pathol. 14:233-238.

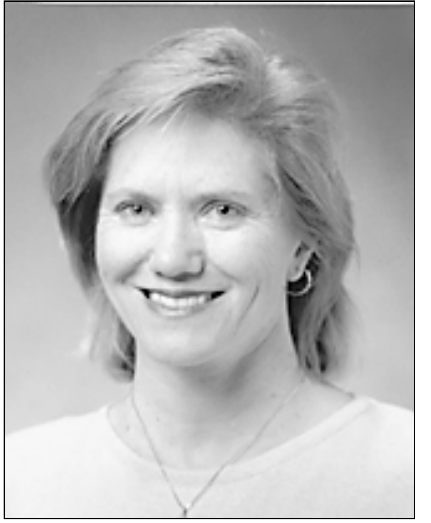

Marcia McMullen

Dr. McMullen is an extension plant pathologist and professor in the Department of Plant Pathology at North Dakota State University. She earned her B.S. and M.S. degrees in botany and plant pathology at lowa State University and her Ph.D. degree in plant pathology at North Dakota State University. She joined the faculty at NDSU in 1984, with responsibility for extension programming and applied research on diseases of cereal and forage crops. She also is the extension IPM coordinator for North $\mathrm{Da}$ kota. Her research interests focus on the survey and detection of small grain diseases and on the integrated management of root, leaf, and head diseases of wheat.

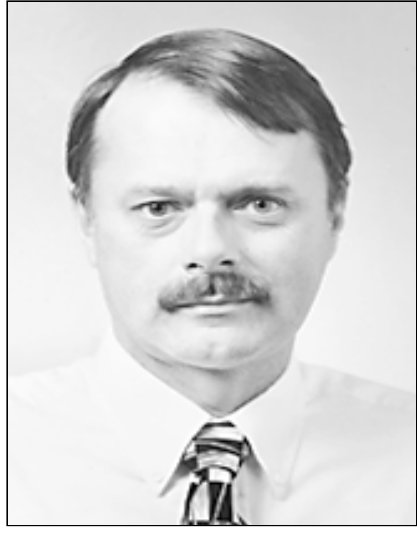

Roger Jones

Dr. Jones is an extension plant pathologist and associate professor in the Department of Plant Pathology at the University of Minnesota, St. Paul. He earned his B.S. degree in population dynamics at the University of Wisconsin-Madison, his M.S. degree in plant pathology at the University of California, Davis, and his Ph.D. degree in plant pathology at North Carolina State University. He was an extension plant pathologist at Texas A\&M University from 1980 to 1988 , and then joined the faculty at the University of Minnesota in August 1988. He develops educational programs on disease management for Minnesota's producers of small grains, sugar beets, and potatoes. His research interests focus primarily on diseases caused by Rhizoctonia and Fusarium fungi.

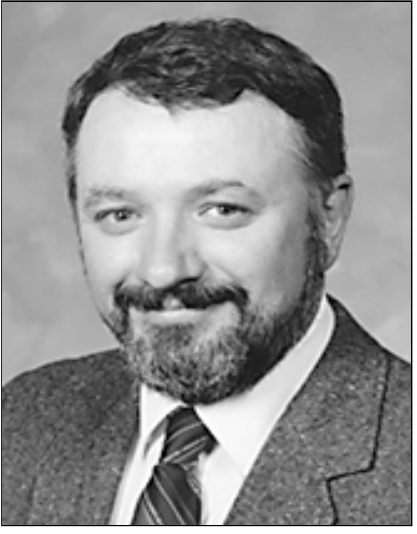

Dale Gallenberg

Dr. Gallenberg is a plant pathologist and head of the Department of Plant Science at South Dakota State University. He obtained his B.S. degree in horticulture and plant pathology at the University of Wisconsin-Madison and his M.S. and Ph.D. degrees in plant pathology at Cornell University. He joined the faculty at SDSU in 1984 as an extension plant pathologist, with responsibilities for disease identification and disease management of all crops grown in the state. He also was responsible for supervising the Plant Disease Clinic. His research focused on evaluation of foliar and seed treatment fungicides on small grains and soybeans. He assumed his present position as head of a multidisciplinary department on 1 January 1996. 